University of Nebraska - Lincoln

DigitalCommons@University of Nebraska - Lincoln

\title{
Partitioning the Genetic Variability for Seedling Growth in Sand Bluestem into Its Seed Size and Seedling Vigor Components
}

Keith L. Glewen

University of Nebraska-Lincoln, kglewen1@unl.edu

Kenneth P. Vogel

University of Nebraska-Lincoln, kvogel1@unl.edu

Follow this and additional works at: https://digitalcommons.unl.edu/usdaarsfacpub

Glewen, Keith L. and Vogel, Kenneth P., "Partitioning the Genetic Variability for Seedling Growth in Sand Bluestem into Its Seed Size and Seedling Vigor Components" (1984). Publications from USDA-ARS / UNL Faculty. 1869.

https://digitalcommons.unl.edu/usdaarsfacpub/1869

This Article is brought to you for free and open access by the U.S. Department of Agriculture: Agricultural Research Service, Lincoln, Nebraska at DigitalCommons@University of Nebraska - Lincoln. It has been accepted for inclusion in Publications from USDA-ARS / UNL Faculty by an authorized administrator of DigitalCommons@University of Nebraska - Lincoln. 


\title{
Partitioning the Genetic Variability for Seedling Growth in Sand Bluestem into Its Seed Size and Seedling Vigor Components ${ }^{1}$
}

\author{
K. L. Glewen and K. P. Vogel ${ }^{2}$
}

\begin{abstract}
Spaced plants of 'Goldstrike' sand bluestem (Andropogon hallii Hack.) were used to obtain estimates of the genetic variances for caryopsis weight, seedling weight at 8 weeks which was used as a measure of seedling growth, and 1 st year forage yields. Since caryopsis weight has a positive effect on seedling weight, seedling weights were adjusted for caryopsis weight using regression analyses. Adjusted seedling weights are a measure of seedling growth with the effect of seed size excluded and as such were used as an estimate of seedling vigor. Heritability estimates were calculated using variance components. The broad-sense heritability estimate for caryopsis weight was 0.87 while the narrowsense heritability estimates for seedling weight, adjusted seedling weight (seedling vigor), and 1st year forage yield were 0.37 , 0.22 , and 0.63 , respectively. As indicated by the heritability estimates, almost half of the genetic variability for seedling weight was due to variation for caryopsis weight while the remaining genetic variability was due to seedling vigor. The genetic correlation of caryopsis weight and seedling weight was 0.70 . Selection for seedling weight by indirect selection for caryopsis weight would result in expected gains from selection almost as large as those for direct selection for seedling weight. However, the genotypes selected by the two methods would not be identical. Selection for seedling weight involves selection for both seed weight and seedling vigor and should optimize breeding gains for improved seedling vigor. The correlations of caryopsis weight and seedling weight with post-establishment 1st year forage yield were small $(r \leq 0.15)$.
\end{abstract}

Additional index words: Seedling vigor, Quantitative genetics, Establishment, Warm-season grass.

M ANY perennial forage grasses are often difficult to establish, particularly in arid and semiarid areas, because of environmental stress and because of poor seedling vigor. Even in more humid areas, establishment is often slower than that of weedy annual grasses. As a result, considerable research has been conducted on improving the establishment capability of both warm- and cool-season grasses by breeding strains with improved seedling vigor. In virtually all of the research that has been done to date, seed size or seed weight has been shown to be an important component of seedling growth (McKell, 1972; Kneebone, 1972). Breeding for improved seed size can result in strains with improved seedling growth and establishment (Trupp and Carlson, 1971 ; Wright, 1977; Clements and Latter, 1973).

Seed size is, however, only a component of seedling growth. Whalley et al. (1966) subdivided seedling growth into a heterotropic stage, a transition stage, and an autotropic stage. The heterotropic stage included all physiological activities prior to the initiation of photosynthesis, and the autotropic stage occurs after all endosperm reserves have been depleted. The effect of seed size probably occurs in the heterotropic and transitional stages and it may also have a carryover effect in the autotropic stage. Variation for seedling growth within a species is thus due to variation for seed weight and seedling vigor. For the purposes of this paper, seedling vigor is defined as all components of seedling growth with the effect of seed weight excluded and could consist of physiological processes in the heterotropic, transitional, and autotropic stages of seedling growth.

Sand bluestem (Andropogon hallii Hack.) is a warmseason, cross-pollinated perennial grass that is adapted to sandy sites throughout the Great Plains including the Sandhills of Nebraska, an area of five million hectares (Keech and Benthall, 1971). In a previous study with sand bluestem, Kneebone and Cremer (1955) sized seed from 'Woodward' and a common Oklahoma seed lot into four seed-size classes. Seed size had little effect on germination but emergence and growth rate were faster for seedlings from the

\footnotetext{
' Contribution from the USDA/ARS and the Nebraska Agric. Exp. Stn. Published as Paper No. 6025, Journal Series, Nebraska Agric. Exp. Stn. Research is based on a thesis presented by K.L. Glewen to the faculty of the Graduate College of the Univ. of Nebraska in partial fulfiliment of the requirements of the M.S. degree. Received 9 Mar. 1983.

${ }^{2}$ County extension agent, Saunders County, Nebr, , formerly research technician, Univ. of Nebraska, and research agronomist, USDA/ARS, Univ. of Nebraska-Lincoln, Lincoln, NE 68583.
} 
high than from the low seed-weight class. Kneebone (1956) also investigated the potential for breeding for seedling vigor in sand bluestem with collections from Kansas, Oklahoma, and Texas. The 3-year mean 500seed weight of clones from these collections ranged from 0.56 to $2.05 \mathrm{~g}$. Phenotypic correlations between parent 500-seed weight for 72 entries and progeny stand, seedling vigor scores, and 1st-year forage yields were $r=0.88,0.44$, and 0.40 , respectively. Kneebone (1956) also reported a correlation of $r=0.34$ between parent and half-sib progeny seed weight. Heritability estimates and estimates of genetic variances for seed weight, seedling vigor, and 1st-year forage yields have not been previously reported for sand bluestem.

The objectives of this research were to: 1) obtain estimates of the genetic variability for seed size and seedling growth for a sand bluestem population indigenous to the central Great Plains, 2) partition the genetic variability for seedling growth into seed size and seedling vigor components, and 3) obtain estimates of the gain that could be obtained by breeding for seedling growth when selection was for seed size, seedling growth, or for seedling vigor.

\section{MATERIALS AND METHODS}

In the fall of 1974 and the spring of 1975,147 sand bluestem plants were visually selected for vigor and forage productivity from two space-planted Goldstrike Syn-1 nurseries containing 1000 plants each at the Univ. of Nebraska Field Laboratory at Mead, Nebr. Goldstrike was developed from collections in the Nebraska Sandhills by Newell (1973). The selected plants were transplanted into a twice replicated randomized complete block polycross nursery at the Mead Laboratory on 12 and 13 June 1975. Plants were spaced on $1.1 \mathrm{~m}$ centers with one ramet (clonal unit) of each plant in a replication.

Seed was harvested on 30 Sept. and 1 Oct. 1976 and on 20 and 21 Sept. 1977 on an individual plant basis. The seed unit of sand bluestem is the fertile spikelet, raceme joint, and the sterile spikelet stalk (Wheeler and Hill, 1975). Racemes were cut from plants with hand sickles and threshed with a small plot thresher. The individual plant seed lots were dried in a greenhouse in small paper bags. Seed yields were not determined because of the difficulty of threshing, processing, and determining purity of the chaffy seed lots. In the early spring of each harvest year, the plants were burned to remove residual forage from the previous year and cultivated with a roto-tiller that trimmed all plants to a uniform size of $0.25 \mathrm{~m}^{2}$. Atrazine was used for weed control. In 1976 the nursery was fertilized with $138 \mathrm{~kg} /$ ha $\mathrm{N}$ and in 1977 with $112 \mathrm{~kg} / \mathrm{ha} \mathrm{N}$ and with $12 \mathrm{~kg} / \mathrm{ha}$ $P$.

Seed was processed by rubbing the caryopses free of the florets using a rubber rubbing board and then separating the caryopses from the chaff by using an air blower. Caryopses were used as the seed unit to eliminate the possibility of using any unfilled florets in the study. Hundred caryopsis weight was determined using the caryopses from individual plants for both years.

Caryopses were planted in a greenhouse experiment to test for seedling vigor as measured by seedling dry weight 2 months after seeding. Cone-tainer fir cells ${ }^{3}$ which are 12 $\mathrm{cm}$ long and $2.5 \mathrm{~cm}$ in diameter were used to grow the seedlings. Cone-tainer cells were filled with a mixture of soil, peat, and vermiculite at a volume ratio of $2: 1: 1$. The
Table 1. Analyses of variance form, expected mean squares and, variance components from the analyses of hundred caryopsis weight of Goldstrike sand bluestem parent clones.

\begin{tabular}{|c|c|c|c|c|}
\hline \multirow[b]{2}{*}{$\begin{array}{l}\text { Source of } \\
\text { variation }\end{array}$} & \multirow[b]{2}{*}{ df } & \multirow[b]{2}{*}{$\begin{array}{l}\text { Expected } \\
\text { mean squares }\end{array}$} & \multicolumn{2}{|c|}{ Variance components } \\
\hline & & & $\begin{array}{c}\text { Com- } \\
\text { ponent }\end{array}$ & $\begin{array}{l}\text { Estimate } \\
\quad \pm \text { SE }\end{array}$ \\
\hline & & & & mg \\
\hline $\begin{array}{l}\text { Replications } \\
\text { Genotypes }\end{array}$ & $\begin{array}{l}r-1 \\
g-1\end{array}$ & $\sigma^{2}+\underset{\sigma_{\mathrm{g}}^{2}}{\mathrm{y} \sigma_{\mathrm{gx}}^{2}}+\mathbf{r} \sigma_{\mathrm{gy}}^{2}$ & $\sigma_{\mathrm{g}}^{2}$ & $4370 \pm 634^{* *}$ \\
\hline $\begin{array}{l}\text { Error a } \\
\text { Years }\end{array}$ & $\begin{array}{c}(g-1)(r-1) \\
y-1\end{array}$ & $\begin{array}{c}\sigma^{2}+\mathrm{y} \sigma_{\mathrm{gr}}^{2} \\
\sigma^{2}+\mathrm{r} \sigma_{\mathrm{gy}}^{2}+\mathrm{g} \sigma_{\mathrm{ry}}^{2} \\
+\mathrm{rg} \sigma_{\mathrm{y}}^{2}\end{array}$ & $\begin{array}{l}\sigma_{\mathrm{gx}}^{z} \\
\sigma_{\mathrm{y}}^{2}\end{array}$ & $\begin{array}{c}64 \pm 35 \\
648 \pm 535^{* *}\end{array}$ \\
\hline $\begin{array}{l}\text { Years } x \\
\text { genotypes } \\
\text { Years } x\end{array}$ & $(y-1)(g-1)$ & $\sigma^{3}+r \sigma_{g y}^{3}$ & $\sigma_{\mathrm{g} y}^{2}$ & $292 \pm 62^{* *}$ \\
\hline $\begin{array}{l}\text { replications } \\
\text { Error b }\end{array}$ & $\begin{array}{c}(y-1)(r-1) \\
(y-1)(r-1)(g-1)\end{array}$ & $\frac{\sigma^{2}}{\sigma^{3}}+\mathbf{g} \sigma_{\mathrm{ry}}^{2}$ & $\begin{array}{l}\sigma_{\mathrm{ry}}^{2} \\
\sigma^{2}\end{array}$ & $\begin{array}{rr}5 \pm & 6 \\
287 \pm & 39\end{array}$ \\
\hline
\end{tabular}

** Mean square in ANOVA was significant at the 0.01 level of probability for this source of variation.

cone cells fit into trays with 20 rows of 10 cells per row. A greenhouse progeny plot consisted of one row of 10 cells. The experimental design was a randomized complete block with two replications. Seed from replication 1 of the field polycross nursery was used to plant the progeny plot in replication 1 in the greenhouse. The same procedure was used for the second replication. Each clone of the genotype was represented twice in a greenhouse replication, with one plot planted with seed harvested in 1976 and one with seed harvested in 1977. Years of seed harvest was considered to be an independent variable and half-sib family plots for each year's harvest were randomized accordingly within replications. Seed from only 117 genotypes were planted in the greenhouse because those that produced less than 100 seeds for a particular field replication or year were excluded from the study.

Approximately two seeds were planted per cell on 15 and $16 \mathrm{Feb}$. 1978. Seed was covered in each cell to a depth of $1 \mathrm{~cm}$ with the soil mixture. Captan was applied prior to and immediately following planting to prevent damping off. Seven days after planting, emergence exceeded $50 \%$. Stands were thinned to one seedling per cell on 25, 26, and 27 February and were fertilized with a liquid fertilizer solution (12-6-6) on 14 and 29 March.

On 7 and 8 Apr. 1978 seedling shoots were harvested on a plot basis. Seedlings were cut at a height of $1 \mathrm{~cm}$ above the soil level, placed in paper bags, oven-dried at $65^{\circ} \mathrm{C}$ and then weighed. Because some cells did not contain seedlings, the number of seedlings per plot was recorded and the mean seedling dry weight per plot was calculated. Seedling shoot weight at 8 weeks was used as the measure of seedling growth in this study. The seedlings, which were allowed to regrow after shoot harvest, were half-sib progenies of openpollinated parents.

On 1 and 2 June 1978 the surviving seedlings were transplanted into a nursery at the Mead Field Laboratory using the same experimental design as in the greenhouse except plots were single rows of five plants spaced on $1.1 \mathrm{~m}$ centers. Remnant plants were used to establish a one-row border around the nursery and to fill voids in plots with less than five plants. First-year forage yields were harvested on 5 and 6 Oct. 1978 on a plot basis with the exception that plants used to fill voids in plots were not harvested. Mean single-

\footnotetext{
${ }^{3}$ Mention of a trademark, proprietary product or vendor does not constitute a guarantee or warranty of the product by the USDA and does not imply its approval to the exclusion of other products or vendors that may also be suitable.
} 
Table 2. Analyses of variance form, expected mean squares, and variance components for seedling weight and first year forage yields of Goldstrike sand bluestem half-sib progenies.

\begin{tabular}{|c|c|c|c|c|c|c|}
\hline \multirow[b]{3}{*}{ Source of variation } & \multirow[b]{3}{*}{ df } & \multirow[b]{3}{*}{$\begin{array}{l}\text { Expected } \\
\text { mean squared }\end{array}$} & \multicolumn{4}{|c|}{ Variance components } \\
\hline & & & \multirow[b]{2}{*}{ Component } & \multicolumn{3}{|c|}{ Estimate $\pm \mathrm{SE}$} \\
\hline & & & & Seedling wt. & $\begin{array}{l}\text { Seedling wt. } \\
\text { adjusted for } \\
\text { caryopsis wt. }\end{array}$ & $\begin{array}{l}\text { First-year } \\
\text { forage yield }\end{array}$ \\
\hline & & & & \multicolumn{2}{|c|}{ — $\mathrm{mg} /$ seedling $\longrightarrow$} & g/plant \\
\hline Replications & $(r-1)$ & & & & & \\
\hline Genotypes & $(g-1)$ & $\sigma^{2}+r \sigma_{g y}^{2}+r y \sigma_{g}^{2}$ & $\sigma_{\mathrm{g}}^{2}$ & $42 \pm 19^{* *}$ & $21 \ddagger \pm 16$ & $2080 \pm 483^{* *}$ \\
\hline Yearst & $(y-1)$ & $\sigma^{2}+r \sigma_{g y}^{2}+r g \sigma_{y}^{2}$ & $\sigma_{\mathbf{y}}^{5}$ & $-1 \pm 1$ & $-1 \pm 1$ & $-1 \pm 18$ \\
\hline Genotypes $\times$ years & $(g-1)(y-1)$ & $\sigma^{2}+\mathbf{r} \sigma_{g y}^{2}$ & $\sigma_{\mathrm{gy}}^{2}$ & $0 \pm 24$ & $-8 \pm 24$ & $-890 \pm 465$ \\
\hline Error & $(g y-1)(r-1)$ & $\sigma^{2}$ & $a^{2}$ & $292 \pm 28$ & $295 \pm 29$ & $6652 \pm 648$ \\
\hline
\end{tabular}

** Mean square in ANOVA was significant at the 0.01 level of probability, for this source of variation.

+ Years refers to years of seed harvest.

$\ddagger$ Level of probability $=0.089$

Table 3. Means and ranges for hundred caryopsis weight of parental plants and seedling weight, adjusted seedling weight, and 1-year forage yields of half-sib progenies of Goldstrike sand bluestem genotypes.

\begin{tabular}{lrrr}
\hline & & \multicolumn{2}{c}{ Range } \\
\cline { 4 - 5 } Trait & Mean \pm SD & Low & High \\
\hline Parents: & & & \\
Hundred caryopsis weight $(\mathrm{mg})$ & $374 \pm 32 \dagger$ & 219 & 547 \\
Progeny: & & & \\
Seedling weight (mg/seedling) & $97 \pm 17$ & 69 & 126 \\
Adjusted seedling weight (mg/seedling) & $97 \pm 17$ & $\mathbf{7 5}$ & 119 \\
First year forage yield (g/plant) & $214 \pm 70$ & 124 & 370 \\
\hline
\end{tabular}

$\dagger \mathrm{SD}=\sqrt{\text { error }}$ mean square for genotypes.

plant yields were determined by dividing plot yields by the number of nonfiller plants in a plot. Yields are reported on a fresh weight basis. The mean dry matter content of 18 random samples was $35.1 \%$.

Regression analyses were used to determine the effect of caryopsis weight on seedling weight. The regression of seedling weight on caryopsis weight was calculated for each year of seed production. Seedling weights were then adjusted for caryopsis weight for each seed production year using the regression coefficient and caryopsis mean weight for that year in the following equation: adjusted seedling weight $=$ seedling weight $-\mathrm{b}$ (hundred caryopsis weight - $\mathrm{X}$ hundred caryopsis weight). Seedling weight adjusted for caryopsis weight was used as an estimate of seedling vigor. This procedure was used in lieu of the analysis of covariance because the independent variable (caryopsis weight) was influenced by the treatment effects (genotypes). Analyses of covariance should be used when the independent effect is not influenced by treatments (Steel and Torrie, 1960).

The data for caryopsis weight of the parent clones for 1976 and 1977 were analyzed as a split plot in time (Table 1). The data for seedling weight, seedling weight adjusted for caryopsis weight, and 1st-year forage yield were analyzed using a year of seed harvest $X$ genotype factorial analysis (Table 2). Hundred caryopsis weight was also analyzed by the latter method to obtain the mean products and genotypic covariances needed to calculate phenotypic and genotypic correlations among traits. Estimates of variance components were obtained by equating the mean squares to their expectations and solving the set of simultaneous equations. Standard errors of the variance components were calculated using procedures described by Crump (1951). Complete data sets were available on 105 genotypes and only the results from those genotypes are reported.
The following abbreviations are used in the text and tables: $\mathbf{r}=$ replication, $\mathrm{g}=$ genotypes, $\mathrm{y}=$ years, $\sigma_{\mathrm{g}}^{2}=$ genetic variance, $\sigma_{\mathrm{y}}^{2}=$ variance among years, $\sigma_{\mathrm{gy}}^{2}=$ genotype $X$ year interaction variance, $\sigma^{2}=$ residual mean square; $\sigma_{\mathrm{g}}^{2}$ for the parent clones is the total genetic variance while among the half-sib families it is $1 / 4$ the additive genetic variance $\left(\sigma_{\mathrm{ga}}^{2}\right)$. The formula used for calculating the broadsense heritability estimate for caryopsis weight was: $\mathrm{H}=$ $\sigma_{\mathrm{g}}^{2} /\left(\sigma_{\mathrm{g}}^{2}+\sigma_{\mathrm{gy}}^{2}+\sigma_{\mathrm{gr}}^{2}+\sigma^{2}\right)$. Narrow-sense heritability on a half-sib family mean basis for seedling weight and lst-year forage yield was calculated as: $\mathrm{H}=\sigma_{\mathrm{g}}^{2} / \sigma_{\mathrm{PFM}}^{2}$ where $\sigma_{\mathrm{PFM}}^{2}=$ $\sigma_{\mathrm{g}}^{2}+\sigma_{\mathrm{gy}}^{2} / \mathrm{y}+\sigma^{2} /$ ry. Negative variance components were excluded from these calculations. Although Kneebone (1956) did not report heritability estimates for caryopsis weight, it is possible to convert his parent-progeny correlation into a regression coefficient. A narrow-sense heritability estimate $(\mathrm{H})$ can then be calculated as follows: $\mathrm{H}=$ $2 b=2 r(s y / s x)$ where $b, r, s x$, and sy are the regression coefficient, correlation coefficient, parent standard deviation, and progeny standard deviation, respectively. Assuming that the parent and progeny standard deviations in Kneebone's (1956) study had been the same then sy/sx = 1 and the narrow-sense heritability estimate $(\mathrm{H})$ for caryopsis weight $=2(0.34)=0.68$.

Phenotypic and genotypic correlations were calculated using the following equations: phenotypic correlation $r_{i j}=$ $\mathrm{MP}_{\mathrm{ij}} / \sqrt{\mathrm{MS}_{\mathrm{ii}}} \times \mathrm{MS}_{\mathrm{jj}}$, genotypic correlation $\mathrm{r}_{\mathrm{g}_{\mathrm{ij}}}=\sigma_{\mathrm{gij}_{\mathrm{ij}}} /$ $\sqrt{\sigma_{\mathrm{gii}}^{2} \times \sigma_{\mathrm{Bij}}^{2}} \cdot \mathrm{MP}_{\mathrm{ij}}$ is the mean product for genotype of the $\mathrm{i}$ th and $\mathrm{j}$ th trait and $\mathrm{MS}_{\mathrm{ii}}$ and $\mathrm{MS}_{\mathrm{ij}}$ are the mean squares for genotypes of the $i$ th and $j$ th trait, respectively; $\sigma_{\mathrm{g}_{\mathrm{jij}}}, \sigma_{\mathrm{gij}}^{2}$, and $\sigma_{\mathrm{g}_{\mathrm{ij}}}^{2}$ are the genetic covariance and the genetic variance components for the $i t h$ and $j$ th traits, respectively.

Expected gains from selection $(\Delta G)$ were calculated using equations derived from Falconer (1981) and Nguyen and Sleper (1983) with the assumption that the 10 genotypes with the heaviest caryopsis weight or whose half-sib families had the heaviest seedlings would be transplanted in isolated polycross nurseries. With these restrictions, the gain from selection for caryopsis weight $(\mathrm{X})$ would be: $\Delta \mathrm{G}_{\mathbf{X}}=\mathrm{i} \times$ $\mathrm{H}_{\mathbf{X}} \times \sigma_{\mathbf{P X}}$ where $\mathrm{i}$ is the standardized selection differential obtained from Becker (1975), $\mathrm{H}_{\mathrm{X}}$ is the narrow-sense heritability estimated $(\mathrm{H}=0.68)$ which we calculated from Kneebone's $(1956)$ data, and $\sigma_{\mathrm{PX}}=\left(\sigma_{\mathrm{g}}^{2}+\sigma_{\mathrm{gy}}^{2}+\sigma_{\mathrm{gr}}^{2}\right.$ $\left.+\sigma^{2}\right)^{1 / 2}$ from Table 1 . The correlated response in seedling weight $(y)$ when selection is for caryopsis weight would be: $\Delta \mathrm{G}_{(\mathrm{x})}=\mathrm{i} \times \mathrm{H}_{\mathrm{x}}{ }^{1 / 2} \times \mathrm{r}_{\mathrm{gxy}} \times \sigma_{\mathrm{ga}}^{2} ; \sigma_{\mathrm{ay}}^{2}$ is $4 \times \sigma_{\mathrm{g}}^{2}$ from Table 2.

The expected gain for selection for seedling weight and adjusted seedling weight would be: $\Delta \mathrm{Gy}=\mathrm{c} \times \mathrm{i} \times \mathrm{H} \times$ $\sigma_{\mathrm{PFM}}$ where $\mathrm{c}$ is the parental control factor and is equal to 
2 with the given restrictions (Nguyen and Sleper, 1983) and $\sigma_{\mathrm{PFM}}=\sigma_{\mathrm{PFM}}^{2}{ }^{1 / 2}$ which was defined previously.

\section{RESULTS AND DISCUSSION}

There was considerable variation among the parental clones and their half-sib progenies for all traits (Table 3). The caryopsis weight of the genotype with the heaviest caryopsis weight was $50 \%$ larger than the mean for all genotypes. The half-sib family with the highest mean seedling weight produced seedlings $30 \%$ heavier than the mean seedling weight for all genotypes and the half-sib family with the highest mean 1st-year forage yield had yields $70 \%$ heavier than the mean for all genotypes. Our mean and range values for caryopsis weight and our phenotypic correlation between caryopsis weight and seedling weight (Table 5) are similar to those reported by Kneebone (1956) for seed weight and seedling vigor scores for sand bluestems from the southern Great Plains.

Seed weight had a significant effect on seedling weight in both 1976 and 1977 as indicated by the regression analyses (Table 4 ). The coefficient of determination $\left(R^{2}\right)$ values were small indicating that caryopsis weight had only a small effect on seedling weight.

This is misleading as will be pointed out in the

Table 4. Means, regression coefficients (b), intercepts (a), ' $t$ ' values for the regression coefficients, and coefficients of determination $\left(R^{2}\right)$ for the regression of seedling weight on hundred caryopsis weight.

\begin{tabular}{|c|c|c|c|c|c|c|}
\hline $\begin{array}{c}\text { Year of } \\
\text { seed } \\
\text { harvest }\end{array}$ & $\mathbf{b}$ & $\mathbf{a}$ & ' $t$ ' & $\mathbf{R}^{2}$ & $\begin{array}{c}\overline{\mathrm{X}} \text { hundred } \\
\text { caryopsis } \\
\text { wt. }\end{array}$ & $\begin{array}{c}\overline{\mathrm{x}} \\
\text { seedling } \\
\text { wt. }\end{array}$ \\
\hline & & & & & \multicolumn{2}{|l|}{$\longrightarrow \mathrm{mg}$} \\
\hline $\begin{array}{l}1976 \\
1977\end{array}$ & $\begin{array}{l}0.0758 \\
0.0676\end{array}$ & $\begin{array}{l}66.4 \\
73.3\end{array}$ & $\begin{array}{l}4.8^{* *} \\
3.7^{* *}\end{array}$ & $\begin{array}{l}0.10 \\
0.06\end{array}$ & $\begin{array}{l}392 \\
355\end{array}$ & $\begin{array}{l}96 \\
97\end{array}$ \\
\hline
\end{tabular}

** Indicates significance at the 0.01 level of probability.

Table 5. Heritability estimates and phenotypic and genotypic correlations for hundred caryopsis weight, seedling weight, and 1st-year forage yields of Goldstrike sand bluestem.

\begin{tabular}{|c|c|c|c|c|c|}
\hline \multirow[b]{3}{*}{ Trait } & \multirow{3}{*}{$\begin{array}{c}\text { Herita- } \\
\text { bility } \\
\text { estimate }\end{array}$} & \multicolumn{4}{|c|}{ Correlation with: } \\
\hline & & \multicolumn{2}{|c|}{$\begin{array}{l}\text { Seedling } \\
\text { weight }\end{array}$} & \multicolumn{2}{|c|}{$\begin{array}{l}\text { First year } \\
\text { forage yield }\end{array}$} \\
\hline & & $\begin{array}{l}\text { Pheno- } \\
\text { typic }\end{array}$ & $\begin{array}{l}\text { Geno- } \\
\text { typic }\end{array}$ & $\begin{array}{l}\text { Pheno- } \\
\text { typic }\end{array}$ & $\begin{array}{l}\text { Geno- } \\
\text { typic }\end{array}$ \\
\hline Hundred caryopsis weight & $\begin{array}{l}0.87 \\
0.37\end{array}$ & $0.46^{* *}$ & 0.70 & $\begin{array}{l}0.10 \\
0.12\end{array}$ & $\begin{array}{l}0.14 \\
0.15\end{array}$ \\
\hline Adjusted seedling weight & 0.22 & & & & \\
\hline First-year forage yield & 0.63 & & & & \\
\hline
\end{tabular}

** Indicates significance at the 0.01 level of probability for phenotypic correlations. following discussion. The regression coefficients were positive indicating that seedling weight increases as caryopsis weight increases. The range in adjusted seedling weights (seedling vigor) is smaller than that of unadjusted seedling weight (Table 1). The regression of Ist year forage yields on caryopsis weight (not shown) was not significant.

There were significant differences at $p=0.01$ among genotypes for all traits except for adjusted seedling weights where $p=0.089$ (Tables 1 and 2). Year and year $X$ genotype interaction effects were significant at $p=0.01$ for hundred caryopsis weight for the parent plants but year (seed production) and genotype $X$ year (seed production) effects were not significant for seedling weight and 1st-year forage yields. The effects of years (per se) were not determined for seedling weight and 1 st year forage yield but would probably not be significant for seedling vigor since this trait was measured in a greenhouse where the environment can be controlled. Years (per se) would probably affect lst-year forage yields since this trait was determined in the field. First-year forage yield was included in this study to obtain estimates of phenotypic and genotypic correlations between seedling vigor and post-establishment productivity the year of establishment. The $\sigma_{\mathrm{g}}^{2}$ for $1 \mathrm{st}-$ year forage yield probably is inflated to some extent by $\sigma_{\mathrm{gy}}^{2}$ for the single year of evaluation. Although $\sigma_{\mathrm{y}}^{2}$ and $\sigma_{\mathrm{gy}}^{2}$ were significant for caryopsis weight, $\sigma_{\mathrm{g}}^{2}$ was $460 \%$ larger than their combined effects. This information indicates that seed from a single year's harvest could be used to select for caryopsis weight, seedling shoot weight, and 1st-year forage yields.

The $\sigma_{\mathrm{g}}^{2}$ for adjusted seedling weight is one-half the size of $\sigma_{\mathrm{g}}^{2}$ for seedling weight (Table 2) indicating that approximately half of the genetic variability for seedling weight in sand bluestem is due to variability in caryopsis weight.

The broad-sense heritability estimate for the parent clones was high for caryopsis weight while narrow-sense heritability estimates for seedling weight and 1st-year forage yield were moderately high (Table 5). Nonadditive genetic variance may be included in the broad-sense estimate for caryopsis weight. The heritability estimate for adjusted seedling weight was $40 \%$ smaller than that for seedling weight. The narrow-sense estimate for 1st-year yields may be inflated because $\sigma_{\mathrm{g}}^{2}$ for this trait may be inflated as explained above.

The genotypic correlation between caryopsis weight and seedling weight was high while the phenotypic correlation between the same traits was lower but significant (Table 5) indicating that selection for car-

Table 6. Expected gain from selection for seedling weight in sand bluestem when selection is based upon caryopsis weight, seedling weight, or seedling weight adjusted for caryopsis weight and the mean caryopsis and seedling weights of 10 genotypes (top $9.5 \%$ ) when selection was based on the same three traits.

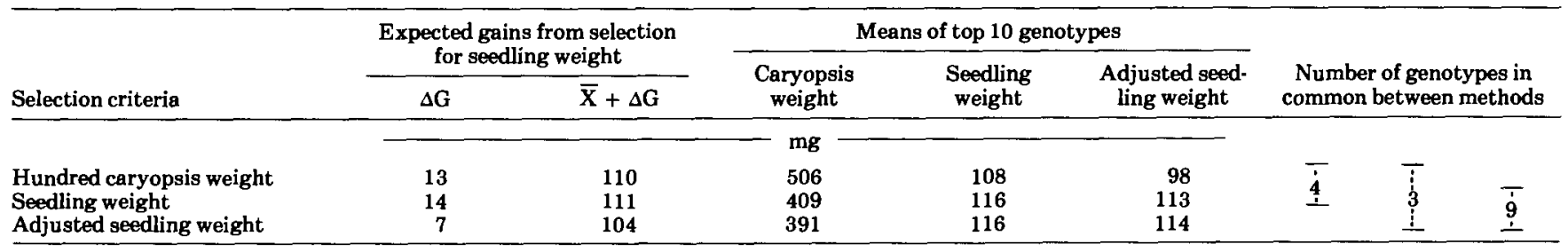


yopsis weight would result in increased seedling weight. The correlation between caryopsis weight and 1st-year forage yield was low as were the correlations between seedling weight and 1st-year forage yield. These results indicate that genotypes with high caryopsis weight produce progenies with heavy seedling weight but that once the progenies are established in the field both traits have only a minimal affect on 1 st-year forage yields.

The expected gain from selection for hundred caryopsis weight was $84 \mathrm{mg}$, which is $22 \%$ of the mean which would indicate that rapid progress can be made in breeding for improved caryopsis weight in sand bluestem. The correlated response in seedling weight when selection is for caryopsis weight was $\Delta \mathrm{Gy}_{(\mathbf{x})}=$ $13 \mathrm{mg}$ which is almost as large as the $\Delta \mathrm{Gy}$ for direct selection for seedling weight (Table 6). Either method of selection would result in gains from selection of over $13 \%$ per cycle for seedling weight. Gains from selection for seedling weight when selection was for seedling weight adjusted for caryopsis weight would result in expected gains of about $7 \%$ per cycle.

Selection for seedling weight involves selection for both the seed weight and seedling vigor components of seedling growth. If these effects are additive, it should give larger gains for selection for seedling weight than would selection for either component. The expected gains from indirect selection for seedling weight by selecting for caryopsis weight was almost as large as the expected gains for direct selection because of the high heritability estimate for caryopsis weight and because the expected gain from selection for seedling weight was based on the evaluation of half-sib families which is not as efficient as selection on an individual plant basis. However, if the means of the 10 genotypes with the largest caryopsis weight, seedling weight, or adjusted seedling weight are compared, the genotypes selected for seedling weight have seedling weights $7 \%$ larger than those selected for caryopsis weight and the two sets of 10 genotypes have only four genotypes in common (Table 6). Selection for seedling weight will result in different genotypes being selected than if selection is for caryopsis weight. Selection for either adjusted seedling weight or seedling weight would have resulted in the selection of essentially the same genotypes.

In summary, there is considerable genetic variability for caryopsis weight and seedling growth as measured by seedling shoot weight 8 weeks after planting in sand bluestem. Since these traits are positively correlated, selection for either trait will result in improved seedling vigor in sand bluestem. Only by direct selection for seedling weight, however, can progress be made in improving the seedling vigor component of seedling growth. In long-term selection programs, the greatest potential improvement in seedling growth can probably be made by selecting for seedling weight. Selection for seedling weight adjusted for seed weight or selection for seedling weight using seed lots sized to a uniform size would be undesirable because the positive effect of seed size on seedling growth would not be utilized.

\section{REFERENCES}

1. Becker, W.A. 1975. Manual of quantitative genetics. 3rd ed. Washington State Univ. Press, Pullman, Wash.

2. Clements, R.J., and B.D.H. Latter. 1973. Responses to selection for seed weight and seedling vigor in Phalaris. Aust. J. Agric. Res. 25:33-34

3. Crump, S.L. 1951. The present status of variance component analyses. Biometrics 7:1-16.

4. Falconer, D.S. 1981. Introduction to quantitative genetics. 2nd ed. Longman Inc., New York, N.Y.

5. Keech, C.F., and R. Benthall. 197I. Dunes on the plains. The Sandhills region of Nebraska. Resource Rep. No. 4, Conservation and Survey Division, Univ. of Nebraska-Lincoln.

6. Kneebone, W.R. 1956. Breeding for seedling vigor in sand bluestem, Andropogon hallii Hack., and other native grasses. Agron. J. 48:37-40.

7. ---. 1972. Breeding for seedling vigor. p. 90-100. In V.B. Younger and C.M. McKell (ed.) The biology and utilization of grasses. Academic Press, New York.

8. - , and C.L. Cremer. 1955. The relationship of seed size and seedling vigor in some native grass species. Agron. J. 47:472-477

9. McKell, C.M. 1972. Seedling vigor and seedling establishment. p. 74-89. In V.B. Younger and C.M. McKell (ed.) The biology and utilization of grasses. Academic Press, New York.

10. Newell, L.C. 1973. Notice of release of Goldstrike sand bluestem. Nebraska Agric. Exp. Stn. and USDA/ARS.

11. Nguyen, H.T., and D.A. Sleper. 1983. A review of theory and application of half-sib mating in forage grass breeding. Theor. Appl. Genet. 64:187-196.

12. Steel, R.G., and J.H. Torrie. 1960. Principles and procedures of statistics. McGraw-Hill Book Co., New York.

13. Trupp, C.R., and I.T. Carlson. 1971. Improvement of seedling vigor of smooth bromegrass by recurrent selection for high seed weight. Crop Sci. 11:225-228.

14. Whalley, R.D.B., C.M. McKell, and L.R. Green. 1966. Seedling vigor and the non-photosynthetic stage of seedling growth in grasses. Crop Sci. 6:147-150.

15. Wheeler, W.A., and D.D. Hill. 1975. Grassland seeds. D. Van Norstrand Co. Inc., Princeton, N. J.

16. Wright, L.N. 1977. Germination and growth response of seed weight genotypes of Panicum antidotale Retz. Crop Sci. 17:176178. 